\title{
PENGARUH TEKNOLOGI BUDIDAYA DAN DOSIS PEMUPUKAN NPK TERHADAP SIFAT KIMIA TANAH DAN PRODUKSI PADI SAWAH (Oryza sativa L.)
}

\author{
Andria Syah Putra ${ }^{1)}$, Sufardi $^{2}$, Fajri $^{3)}$ \\ ${ }^{1)}$ Fakultas Pertanian Universitas Jabal Ghafur, Pidie, Aceh: andria.putra@ yahoo.co.id \\ ${ }^{2 \& 3}$ Fakultas Pertanian Unsyiah, Jl. Tgk. Hasan Krueng Kalee No.3 Darussalam Banda Aceh 23111
}

\begin{abstract}
The objectives of this research aimed to study effects of cultivation technology and appropriate dosages of NPK on Characteristics of Soil Chemistry and rice product. The experiment was arranged in a factorial split plot design with three replicates. Factor of cultivation technology consisted of four levels, i.e. legowo system cultivating, conventional system cultivating, salibu technology, and ratooning technology. Factor of appropriate dosages of NPK consisted of three levels i.e. $100 \mathrm{kgs} \mathrm{ha}^{-1}$ NPK Phonska, $200 \mathrm{kgs} \mathrm{ha}^{-1}$ NPK Phonska, $300 \mathrm{kgs} \mathrm{ha}^{-1}$ NPK Phonska. The result showed that cultivation technology exerted higgly significant effect on $\mathrm{N}$-total, $\mathrm{pH}\left(\mathrm{H}_{2} \mathrm{O}\right), \mathrm{KTK}$, $C$-organic, weight of 1000 grains, numbers of productive tillers, yields, and exert a significant effect on Kdd. Appropriate dosages of NPK exerted highly significant effects on yields and exerted a significant effect on N-total and numbers of productive tillers. Interaction between cultivation technology and appropriate dosages of NPKshowed highly significant on N-total, numbers of production tillers and yields. The highest yields of rice showed by cultivation technologylegowo system with appropriate dosages of $300 \mathrm{kgs} \mathrm{ha}^{-1} \mathrm{NPK}$ Phonska, however based on financial analysis cultivation technology of salibu turned out the best of other cultivation technology since it required minimum cost.
\end{abstract}

\begin{abstract}
Abstrak : Penelitian ini bertujuan untuk mengetahui pengaruh teknologi budidaya dan dosis pemupukan NPK terhadap sifat kimia tanah dan produksi padi sawah. Perlakuan penelitian disusun dalam rancangan petak terbagi pola faktorial dengan 3 ulangan. Perlakuan teknologi budidaya terdiri dari empat taraf yaitu sistem tanam legowo/2:1, sistem tanam konvensional, teknologi salibu, teknologi ratun. Perlakuan dosis pemupukan NPK terdiri dari tiga taraf yaitu perlakuan NPK Phonska $100 \mathrm{~kg} \mathrm{ha}^{-1}$, NPK Phonska $200 \mathrm{~kg} \mathrm{ha}^{-1}$, NPK Phonska $300 \mathrm{~kg} \mathrm{ha}^{-1}$. Hasil penelitian menunjukkan bahwa perlakuan teknologi budidaya memberikan pengaruh sangat nyata terhadap Ntotal, $\mathrm{pH}\left(\mathrm{H}_{2} \mathrm{O}\right)$, KTK, C-organik, berat 1000 butir, jumlah anakan produktif, hasil panen dan memberikan pengaruh nyata terhadap Kdd. Perlakuan dosis pemupukan NPK memberikan pengaruh sangat nyata terhadap hasil panen dan memberikan pengaruh nyata terhadap $\mathrm{N}$-total dan jumlah anakan produktif. Interaksi antara kombinasi perlakuan teknologi budidaya dan dosis pemupukan NPK memberikan pengaruh nyata terhadap N-total, jumlah anakan produktif dan hasil panen. Hasil produksi padi terbaik diperoleh pada teknologi budidaya sistem tanam 2 : 1/Legowo yang disertai dosis pemupukan NPK Phonska $300 \mathrm{~kg} \mathrm{ha}^{-1}$ sedangkan analisis finansial terhadap keempat teknologi budidaya ternyata teknologi salibu lebih unggul dibandingkan sistem tanam legowo dan sistem konvensional karena hemat biaya.
\end{abstract}

Kata kunci : Teknologi budidaya, pemupukan NPK, padi.

\section{PENDAHULUAN}

Padi (Oryza Sativa L.) merupakan bahan makanan pokok yang strategis bagi penduduk Indonesia. Padi dapat ditanam di lahan kering maupun lahan basah (Departemen Pertanian, 2008).

Pertumbuhan penduduk akan meningkatkan kebutuhan beras nasional. Di lain pihak upaya diversifikasi masih belum optimal akibat berbagai hal: teknis, sosial, dan ekonomi (Amang dan Sawit, 2001). Konversi sawah produktif ke sektor non pertanian sulit untuk dihentikan (Ilham et al, 2008), $\mathrm{Hal}$ ini sangat berpengaruh terhadap produksi beras nasional. Untuk memacu peningkatan produksi beras nasional, diperlukan beberapa srategi antara lain: 1) perluasan areal tanam dengan mencetak sawah baru, 2) peningkatan produktivitas lahan dan 3) perluasan areal panen melalui peningkatan IP (indeks panen). Budi daya padi salibu (ratun yang dimodifikasi) dapat memacu peningkatan produksi padi dengan meningkatkan IP (indeks panen).

Budidaya padi sawah saat ini secara umum masih menggunakan sistem konvensional. Budidaya padi konvensional umumnya menggunakan jarak tanam yang rapat sehingga membutuhkan benih dalam jumlah yang banyak (40 $\mathrm{kg}$ per hektar), dengan umur bibit tua (30 hari) pada saat dipindahkan. Pada waktu pemindahan ke lahan, bibit dicabut dan bagian atas dipotong dengan menanam 6 bibit/lubang tanam. Penggunaan bibit yang agak tua dan sudah mempunyai banyak akar akan mengakibatkan bibit mengalami stress dan kerusakan akar. Jarak tanam yang rapat akan menyebabkan jumlah anakan produktif yang rendah yang mengakibatkan produksi rendah dengan rata-rata nasional $4-5$ ton/ha (Uphoff et al, 2008).

Sistem tanam jajar legowo merupakan cara tanam dengan beberapa barisan tanaman kemudian 
diselingi oleh 1 baris kosong dimana jarak tanam pada barisan pinggir $1 / 2$ kali jarak tanaman pada baris tengah. Ada beberapa tipe cara tanam jajar legowo yang umum dilakukan yaitu ; tipe legowo $2: 1$; $3: 1$; $4: 1 ; 5: 1 ; 6: 1$ dan tipe lainnya. Prinsip dari sistem tanam jajar legowo adalah pemberian kondisi pada setiap barisan tanam padi untuk mengalami pengaruh sebagai tanaman barisan pinggir. Umumnya tanaman pinggir menunjukkan hasil lebih tinggi daripada tanaman di bagian dalam barisan. Tanaman pinggir juga menunjukkan pertumbuhan yang lebih baik karena kurangnya persaingan tanaman antar barisan (BPP Kembang Tanjong, 2013).

Menurut Krishnamurthy (1988) dalam Susilawati, (2011) mengatakan bahwa teknologi ratun pada tanaman padi merupakan tunas yang tumbuh dari tunggul batang yang dipanen dan menghasilkan anakan baru hingga dapat dipanen. Praktek budidaya tanaman padi-ratun telah lama dilakukan petani di daerah tropis dan di daerah beriklim sedang. Di Indonesia, budidaya ini banyak dilakukan untuk padi lokal yang berumur panjang. Hasil ratun sering disebut sebagai padi singgang atau turiang. Padi lokal yang berumur panjang, setelah panen tanaman utama, akan dibiarkan oleh petani hingga musim tanam tahun berikutnya. Dalam periode tersebut petani akan memanen ratun dalam waktu sekitar setengah dari periode tanaman utama, dengan produksi berkisar antara $40-60 \%$ dari panen tanaman utamanya.

Padi salibu merupakan sebutan oleh masyarakat Minangkabau terhadap tunas padi yang tumbuh setelah batangnya ketika dipanen. Di daerah lain orang menyebutnya padi suli, padi berlanjut, ratun atau singgang (Jawa) atau turiang (Sunda) atau ciding (Aceh) dan lain-lain sesuai bahasa daerah masingmasing. Selama ini padi salibu hanya dijadikan hijauan makanan ternak, karena gabah yang dihasilkan tidak menguntungkan secara ekonomis.

Padi salibu berbeda dengan padi ratun, ratun adalah padi yang tumbuh dari batang sisa panen tampa dilakukan pemangkasan batang, tunas akan muncul pada buku paling atas, suplay hara tetap dari batang lama (Krishnamurthy, 1988 dalam Susilawati, 2011).

Budidaya padi salibu adalah salah satu inovasi teknologi untuk memacu produktifitas/peningkatan produksi. Pada budidaya padi salibu ada beberapa faktor yang berpengaruh antara lain: 1) tinggi pemotongan batang sisa panen, 2) varietas, 3) kondisi air tanah setelah panen, dan 4) pemupukan. Menurut Yohanes (2012) keuntungan penerapan padi salibu/ratun adalah cepat, mudah dan murah serta dapat meningkatkan produktivitas padi per unit area dan per unit waktu. Penerapan budidaya padi salibu melalui pemanfaatan varietas berdaya hasil tinggi, diduga dapat memberi andil dalam meningkatkan produktivitas padi nasional.

Pemupukan bertujuan menambah persediaan unsur hara yang dibutuhkan oleh tanaman untuk peningkatan produksi dan mutu hasil tanaman. Pupuk menyediakan unsur hara yang kurang atau bahkan tidak tersedia ditanah untuk mendukung pertumbuhan tanaman. Manfaat utama dari pupuk yang berkaitan dengan sifat fisik tanah adalah memperbaiki struktur tanah dari padat menjadi gembur dengan menyediakan ruang pada tanah untuk udara dan air. Dalam Murbandono (2001).

Pemberian pupuk NPK yang mengandung unsur $\mathrm{N}, \mathrm{P}$ dan $\mathrm{K}$ tersebut akan membantu meningkatkan pertumbuhan dan hasil tanaman karena pupuk tersebut berada dalam perbandingan yang tepat (Wahid et al., 2000). Penerapan teknologi yang inovatif dengan input rendah merupakan suatu pilihan dalam mengelola lahan yang ramah lingkungan, berkelanjutan serta dapat memanfaatkan potensi sumberdaya yang tersedia. Salah satu cara untuk meningkatkan dan mempertahankan kesuburan tanah adalah dengan pemupukan NPK.

Berdasarkan uraian tersebut, maka peneliti tertarik ingin mengetahui bagaimana pengaruh teknologi budidaya padi dan dosis pemupukan NPK yang diberikan terhadap sifat kimia tanah dan produksi tanaman padi sawah melalui suatu penelitian yang berlokasi di Gampong Dayah Blang Kecamatan Kembang Tanjung Kabupaten Pidie Provinsi Aceh.

\section{METODOLOGI}

Penelitian ini dilaksanakan pada lahan sawah beririgasi di Gampong Dayah Blang, Kecamatan Kembang Tanjong, Kabupaten Pidie, Provinsi Aceh.Penelitian dalam bulan April 2014 sampai dengan Desember 2014.Bahan-bahan yang digunakan adalah : benih padi varietas Ciherang berlabel ungu, garam dapur, pupuk organik, jerami padi, pupuk NPK Phonska dengan kandungan N $15 \% ; \mathrm{P}_{2} \mathrm{O}_{5} 15 \%$ dan $\mathrm{K}_{2} \mathrm{O} 15 \%$, pupuk Urea $(46 \% \mathrm{~N})$, pestisida (Virtako, Boster, Kuproxat) dan bambu, kawat bronjong, kawat duri (bahan untuk pagar sawah). Penelitian ini menggunakan rancangan petak terbagi (split plot design) dengan tiga ulangan. Petak utama (main plot) adalah dosis pemupukan NPK terdiri dari tiga taraf dan anak petak (sub plot) adalah teknologi budidaya terdiri dari empat taraf.

Penelitian dilakukan pada 2 kali musim tanam. Musim tanam pertama untuk teknologi Legowo/2:1 dan teknologi konvensional, musim tanam kedua untuk teknologi salibu dan teknologi ratun. Penanaman dilakukan pada plot percobaan dengan ukuran 2,5 m x 2,5 m (luas ubinan). Plot ini dibuat sebelum diberikan pupuk dasar yaitu pupuk organik dan pupuk urea. Untuk mencegah rembesan pupuk antar petak perlakuan, maka tiap petak perlakuan dipisahkan dengan menggunakan pematang. Saluran air dibuat ditepi petakan sedemikian rupa sehingga air yang keluar dari petakan tidak masuk ke petakan yang lain.

Penanaman padi di luas lahan 0,125 Ha (1/2 Naleh) Penanaman dilakukan dengan system legowo 
2: 1 dengan jarak tanam $40 \mathrm{~cm}$ x $20 \mathrm{~cm}$ x $10 \mathrm{~cm}$ dan secara konvensional dengan jarak tanam $20 \mathrm{~cm}$ x 20 $\mathrm{cm}$ sesuai dengan masing-masing perlakuan. Setiap lubang ditanami dua batang bibit padi yang baru dicabut dari persemaian. Umur bibit padi dipindahkan ke lapangan umur 16 hari setelah semai. Penanaman dilakukan serentak dalam satu hari seluruh plot percobaan.

Pemberian pupuk NPK diberikan saat tanam 1/3 dosis, umur 25 hari $1 / 3$ dosis dan umur 40 hari $1 / 3$ dosis disesuaikan menurut dosis perlakuan masingmasing. Pupuk NPK Phonska di taburkan secara merata ke dalam plot percobaan. Pemupukan dasar dilakukan sehari sebelum tanam yaitu pemberian pupuk organik semua plot. Urutan kerja teknologi salibu setelah panen MT-1 induknya ; batang bawah dipotong ulang dengan tinggi $3-5 \mathrm{~cm}$ pada $7-10$ Hari setelah panen (HSP), kemudian 1 minggu setelah potong tanah lembab, minggu ke 2 baru diairi. Umur 20 - 25 hari setelah panen (HSP) padi dilakukan penjarangan, penyulaman, pemupukan, penyiangan dan pembenaman jerami. Sedangkan plot penelitian yang menggunakan perlakuan budidaya padi teknologi ratun batang bawah tidak dipotong kembali setelah panen. Untuk pengaturan air, penjarangan, penyulaman, pemupukan, penyiangan tetap dilakukan seperti budidaya padi lainnya.

\section{pH $\mathrm{H}_{2} \mathrm{O}$}

\section{HASIL DAN PEMBAHASAN}

Hasil analisis ragam menunjukkan bahwa $\mathrm{pH}$ $\mathrm{H}_{2} \mathrm{O}$ tidak dipengaruhi nyata oleh pemberian NPK Phonska dan dipengaruhi sangat nyata oleh teknologi budidaya serta tidak saling berinteraksi. Rata-rata $\mathrm{pH}$ $\mathrm{H}_{2} \mathrm{O}$ tanah akibat perlakuan teknologi budidaya dapat dilihat pada Tabel 1 .

Tabel 1. Rata-rata $\mathrm{pH} \quad \mathrm{H}_{2} \mathrm{O}$ akibat perlakuan teknologi budidaya

\begin{tabular}{ll}
\hline Teknologi Budidaya & $\mathrm{pH} \mathrm{H}_{2} \mathrm{O}$ \\
\hline Sistem tanam 2:1 $\left(\mathrm{T}_{1}\right)$ & $6,864 \mathrm{~b}$ \\
Tanam konvensional $\left(\mathrm{T}_{2}\right)$ & $6,948 \mathrm{~b}$ \\
Teknologi Salibu $\left(\mathrm{T}_{3}\right)$ & $6,116 \mathrm{a}$ \\
Teknologi Ratun $\left(\mathrm{T}_{4}\right)$ & $6,110 \mathrm{a}$ \\
\hline
\end{tabular}

Keterangan: Angka-angka yang diikuti dengan huruf yang tidak sama berbeda nyata menurut uji BNT 0,05

Tabel 1 menunjukkan bahwa rata-rata nilai $\mathrm{pH}$ $\mathrm{H}_{2} \mathrm{O}$ tanah akibat pengaruh interaksi antara teknologi budidaya dan pemberian NPK Phonska berkisar


konsisten meningkat seiring dengan perlakuan teknologi budidaya dan dosis pemupukan NPK Phonska. Pada sistem tanam konvensional dengan dosis pemupukan NPK Phonska $200 \mathrm{~kg} \mathrm{ha}^{-1}$ mampu meningkatkan $\mathrm{pH} \mathrm{H}_{2} \mathrm{O}$ dari 5,69 pada analisis tanah awal menjadi 7,01 pada saat setelah panen.

\section{C-organik}

Hasil analisis menunjukkan bahwa kadar Corganik dipengaruhi sangat nyata oleh teknologi budidaya tetapi tidak dipengaruhi secara nyata oleh dosis pemupukan NPK Phonska serta tidak saling berinteraksi. Rata-rata C-organik tanah akibat perlakuan teknologi budidaya dapat dilihat pada Tabel 2.

Tabel 2. Rata-rata C-Organik akibat perlakuan teknologi budidaya

\begin{tabular}{lc}
\hline \multicolumn{1}{c}{ Teknologi Budidaya } & C-organik $(\%)$ \\
\hline Sistem tanam $2: 1\left(\mathrm{~T}_{1}\right)$ & $1,276 \mathrm{a}$ \\
Tanam konvensional $\left(\mathrm{T}_{2}\right)$ & $1,084 \mathrm{a}$ \\
Teknologi Salibu $\left(\mathrm{T}_{3}\right)$ & $1,818 \mathrm{~b}$ \\
Teknologi Ratun $\left(\mathrm{T}_{4}\right)$ & $1,877 \mathrm{~b}$ \\
\hline
\end{tabular}

Keterangan: Angka-angka yang diikuti dengan huruf yang tidak sama berbeda nyata menurut uji BNT 0,05

Tabel 2 memperlihatkan bahwa rata-rata Corganik meningkat secara konsisten seiring dengan perlakuan teknologi salibu dan teknologi ratun yang dicobakan. Nilai C-organik tertinggi dijumpai pada perlakuan Teknologi Ratun dengan dosis pemupukan NPK $100 \mathrm{Kg} \mathrm{ha}^{-1}$ yaitu $1,93 \%$.

Selama penelitian telah terjadi dekomposisi bahan organik yang tersisa dari pemanenan sebelumnya yang dapat membebaskan sejumlah $\mathrm{CO}_{2}$. Hal ini sesuai dengan pendapat (Hakim et al., 1986) yang menyatakan proses dekomposisi bahan organik dapat membebaskan karbon demikian pula akar tanaman juga melepaskan $\mathrm{CO}_{2}$. Teknologi salibu dan teknologi ratun efektif dalam meningkatkan sifat fisik tanah dan mempengaruhi $\mathrm{pH}$ tanah hingga mendekati netral, ini disebabkan karena peluang pengembalian jerami dan batang padi lebih besar ke dalam tanah sehingga bahan organik menjadi bertambah dalam tanah.

\section{N-Total Tanah}

Hasil analisis menunjukkan bahwa kadar Ntotal tanah dipengaruhi nyata oleh pemberian NPK Phonska dan dipengaruhi sangat nyata oleh teknologi budidaya yang dilakukan serta saling berinteraksi. Rata-rata kadar N-total tanah akibat pemberian NPK Phoska dan teknologi budidaya dapat dilihat pada tabel 3.

Tabel 3..Rata-rata N-total tanah akibat perlakuan teknologi budidaya dan dosis Pemupukan NPK

\begin{tabular}{cccc}
\hline \multirow{2}{*}{ Teknologi Budidaya } & \multicolumn{4}{c}{ NPK Phonska $\left(\mathrm{Kg} \mathrm{ha}^{-1}\right)$} \\
& 100 & 200 & 300 \\
\hline & $\ldots \ldots \ldots \ldots \ldots \ldots \ldots \ldots \ldots \ldots \ldots$ \\
\hline Sistem tanam 2:1 $\left(\mathrm{T}_{1}\right)$ & $0,14 \mathrm{a}$ & $0,19 \mathrm{a}$ & $0,18 \mathrm{a}$ \\
& $\mathrm{A}$ & $\mathrm{B}$ & $\mathrm{B}$ \\
Tanam konvensional $\left(\mathrm{T}_{2}\right)$ & $0,15 \mathrm{a}$ & $0,18 \mathrm{a}$ & $0,17 \mathrm{a}$ \\
& $\mathrm{A}$ & $\mathrm{B}$ & $\mathrm{AB}$ \\
Teknologi Salibu $\left(\mathrm{T}_{3}\right)$ & 0,25 & 0,24 & $0,24 \mathrm{~b}$ \\
\hline
\end{tabular}




\begin{tabular}{cccc}
\hline & $\mathrm{bA}$ & $\mathrm{bA}$ & $\mathrm{A}$ \\
Teknologi Ratun $\left(\mathrm{T}_{4}\right)$ & $0,23 \mathrm{a}$ & $0,23 \mathrm{a}$ & $0,21 \mathrm{a}$ \\
& $\mathrm{B}$ & $\mathrm{B}$ & $\mathrm{B}$ \\
\hline
\end{tabular}

Keterangan: Angka-angka yang diikuti dengan huruf yang tidak sama berbeda nyata menurut uji BNT 0,05. Huruf kecil dibaca vertikal huruf besar dibaca horizontal

Tabel 3 memperlihatkan bahwa rata-rata nilai $\mathrm{N}$-Total akibat pengaruh interaksi antara teknologi budidaya dan pemberian NPK Phonska berkisar antara $0,14 \%$ sampai dengan $0,25 \%$. Nilai N-total pada musim tanam kedua cendrung meningkat seiring dengan bertambahnya pupuk urea dari musim tanam pertama dan yang paling tinggi nilai $\mathrm{N}$ dijumpai pada perlakuan teknologi salibu. Sedangkan pada teknologi salibu nilai $\mathrm{N}$-total tertinggi dijumpai pada pemberian NPK Phonska $100 \mathrm{~kg} \mathrm{ha}^{-1}$ yaitu 0,25 $\%$ yang berbeda nyata dengan setiap perlakuan dosis NPK Phonska yang dicobakan.

Perlakuan teknologi budidaya dan pemberian NPK Phonska dapat merubah sifat kimia tanah dengan meningkatnya kadar $\mathrm{N}$-total tanah, terutama pada kombinasi perlakuan antara NPK Phonska 100 $\mathrm{kg}$ ha $^{-1}$ dengan urea $250 \mathrm{~kg} \mathrm{ha}^{-1}$ karena keduanya mampu meningkatkan $\mathrm{N}$-total tanah sebesar $0,05 \%$ terhadap kondisi $\mathrm{N}$-total hasil analisis awal yaitu 0,20 $\%$ yang termasuk kriteria sedang (Sulaeman et al., 2005).

Hal ini disebabkan karena mulai terjadi interaksi antara perlakuan teknologi budidaya dan dosis pemupukan NPK Phonska yang dapat memperbaiki sifat fisik, kimia dan hayati tanah, efektif dalam meningkatkan sifat fisik tanah seperti agregat tanah dan kemampuan tanah mengikat air. Pada tanah berliat, teknologi salibu dapat membantu menurunkan kekerasan tanah dan mempertinggi kemampuan pengikatan air tanah, sehingga berpengaruh terhadap aktivitas mikroorganisme tanah. Penggunaan teknologi salibu di lahan sawah dapat meningkatkan jumlah bakteri fiksasi nitrogen (Azotobacter) di dalam tanah terutama di sekitar akar tanaman pangan (Badan Penelitian dan Pengembangan Pertanian, 1988).

Unsur hara $\mathrm{N}$ berfungsi dalam mempercepat pertumbuhan tanaman yang dalam hal ini menambah tinggi tanaman, jumlah anakan, menambah ukuran daun dan besar gabah serta memperbaiki kualitas tanaman dan gabah, menambah kadar protein beras, meningkatkan jumlah gabah dan persentase jumlah gabah isi menyediakan bahan makanan bagi mikrobia (jasad-jasad renik yang bekerja menghancurkan bahan-bahan organik di dalam tanah) (Dobermann dan Fairhust, 2000).

\section{P-Tersedia dan K-dd}

Hasil analisis menunjukkan bahwa kadar PTersedia tidak dipengaruhi nyata oleh pemberian NPK Phonska dan teknologi budidaya serta tidak saling berinteraksi, tetapiberpengaruh nyata terhadap
K-dd. Rata-rata K-dd akibat perlakuan teknologi budidaya dapat dilihat pada Tabel 4 .

Tabel 4. Rata-rata K-dd akibat perlakuan teknologi budidaya

\begin{tabular}{lc}
\hline \multicolumn{1}{c}{ Teknologi Budidaya } & $\begin{array}{c}\mathrm{Kdd} \\
\left(\mathrm{cmol} \mathrm{kg}^{-1}\right)\end{array}$ \\
\hline Sistem tanam 2:1 $\left(\mathrm{T}_{1}\right)$ & $1,181 \mathrm{ab}$ \\
Tanam konvensional $\left(\mathrm{T}_{2}\right)$ & $1,259 \mathrm{~b}$ \\
Teknologi Salibu $\left(\mathrm{T}_{3}\right)$ & $1,072 \mathrm{a}$ \\
Teknologi Ratun $\left(\mathrm{T}_{4}\right)$ & $1,003 \mathrm{a}$ \\
\hline
\end{tabular}

Ket: Angka-angka yang diikuti dengan huruf yang tidak sama berbeda nyata menurut uji BNT 0,05

Tabel 4 memperlihatkan bahwa rata-rata nilai K-dd akibat pengaruh interaksi antara teknologi budidaya dan dosis pemupukan NPK Phonska berkisar antara $0,92 \mathrm{cmol} \mathrm{kg}^{-1}$ sampai dengan 1,35 terjadi kenaikan terhadap nilai K-dd kondisi awal sebelum penelitian yaitu $0,38 \mathrm{cmol} \mathrm{\textrm {kg } ^ { - 1 }}$. Nilai K-dd terendah dijumpai pada perlakuan Teknologi Ratun dengan dosis pemupukan NPK $300 \mathrm{~kg} \mathrm{ha}^{-1}$ sedangkan nilai K-dd tertinggi dijumpai pada perlakuan Sistem tanam $2: 1$ dengan dosis pemupukan NPK $200 \mathrm{~kg}$ ha ${ }^{1}$, Nilai K-dd tertinggi juga dijumpai pada Sistem Tanam Konvensional dengan dosis pemupukan NPK $100 \mathrm{~kg} \mathrm{ha}{ }^{-1}$. Meningkatnya K-tersedia tanah disebabkan penambahan dari dekomposisi jerami selama berlangsungnya penelitian, penambahan pupuk NPK Phonska sesuai dengan kebutuhan unsur hara dalam tanah serta dari air irigasi digunakan. Menurut Hakim et al. (1986) ketersediaan kalium tanah bertambah oleh adanya penambahan dari luar, dalam hal ini yang dimaksud adalah penambahan melalui air irigasi yang membawa serta lumpur. Hasil penelitian di Jawa Barat menunjukkan bahwa ratarata air irigasi dapat memperkaya tanah sebesar 16 $38 \mathrm{~kg} \mathrm{~K}_{2} \mathrm{O} / \mathrm{ha}$.

Hasil penelitian Ismunadji dan Roechan (1988), menunjukkan bahwa kandungan hara jerami padi adalah : N 0,55 \%; P 0,14 \%; K 1,28\%; Ca 0,13\%; Mg 0,22\% dan S 0,08\%.

Menurud Ahmad (1987), Rosmarkam \& Yuwono (2002) unsur K berperan penting dalam meningkatkan turgor, meningkatkan kadar lignin dan selulosa serta sebagai aktivator enzim. Ismunadji et al. (1987) serta Rosmarkam \& Yuwono (2002) menyatakan bahwa unsur $\mathrm{K}$ berperan penting dalam pembentukan karbohidrat, aktivitas enzim. Selanjutnya De Datta (1981) menyatakan bahwa unsur $\mathrm{K}$ berperan penting dalam pembentukkan anakan, meningkatkan ukuran dan berat biji.

\section{Kapasitas Tukar Kation (KTK)}

Hasil analisis ragam menunjukkan bahwa KTK dipengaruhi sangat nyata oleh teknologi budidaya dan tidak dipengaruhi nyata oleh dosis pemupukan NPK serta tidak saling berinteraksi. Rata-rata kadar KTK akibat perlakuan teknologi budidaya dapat dilihat pada Tabel 5 . 
Tabel 5. Rata-rata KTK akibat perlakuan teknologi budidaya

\begin{tabular}{lc}
\hline \multicolumn{1}{c}{ Teknologi Budidaya } & $\begin{array}{c}\text { KTK } \\
\left(\mathrm{cmol} \mathrm{kg}^{-1}\right)\end{array}$ \\
\hline Sistem tanam 2:1 $\left(\mathrm{T}_{1}\right)$ & $35,778 \mathrm{a}$ \\
Tanam konvensional $\left(\mathrm{T}_{2}\right)$ & $36,778 \mathrm{a}$ \\
Teknologi Salibu $\left(\mathrm{T}_{3}\right)$ & $41,956 \mathrm{~b}$ \\
Teknologi Ratun $\left(\mathrm{T}_{4}\right)$ & $42,311 \mathrm{~b}$ \\
\hline
\end{tabular}

Ket: Angka-angka yang diikuti dengan huruf yang tidak sama berbeda nyata menurut uji BNT 0,05

Tabel 5 menunjukkan bahwa rata-rata KTK menurun terhadap kondisi awal hasil analisis yaitu 42,40 cmol $\mathrm{kg}^{-1}$, namun belum memperlihatkan pengaruh yang nyata. Nilai KTK tertinggi dijumpai pada perlakuan teknologi Ratun dengan dosis pemupukan NPK Phonska $300 \mathrm{Kg} \mathrm{ha}^{-1}$.

KTK dipengaruhi oleh; reaksi tanah, tekstur tanah, jenis mineral liat dan pemupukan serta bahan organik (Hakim et al., 1986).

\section{Jumlah Anakan Produktif Padi}

Jumlah anakan produktif padi dipengaruhi sangat nyata oleh teknologi budidaya dan dipengaruhi nyata oleh dosis pemupukan NPK Phonska serta saling berinteraksi. Rata-rata jumlah anakan produktif padi akibat teknologi budidaya dan dosis pemupukan NPK Phonska dapat dilihat pada Tabel 6.

Tabel 6. Rata-rata jumlah anakan produktif padi akibat perlakuan teknologi budidaya dan dosis pemupukan NPK Phonska

\begin{tabular}{lccc}
\hline Teknologi Budidaya & \multicolumn{4}{c}{ NPK Phonska $\left(\mathrm{Kg} \mathrm{ha}^{-1}\right)$} \\
& 100 & 200 & 300 \\
\hline & $\ldots \ldots .$. Batang & per rumpun...... \\
\hline Sistem tanam 2:1 $\left(\mathrm{T}_{1}\right)$ & $13,2 \mathrm{bc}$ & $15 \mathrm{c}$ & $15 \mathrm{c}$ \\
& $\mathrm{A}$ & $\mathrm{B}$ & $\mathrm{B}$ \\
Tanam konvensional $\left(\mathrm{T}_{2}\right)$ & $12,6 \mathrm{~b}$ & $13 \mathrm{~b}$ & $13 \mathrm{~b}$ \\
& $\mathrm{~A}$ & $\mathrm{~A}$ & $\mathrm{~A}$ \\
Teknologi Salibu $\left(\mathrm{T}_{3}\right)$ & $13,6 \mathrm{c}$ & $14 \mathrm{~b}$ & $14 \mathrm{~b}$ \\
& $\mathrm{~A}$ & $\mathrm{~A}$ & $\mathrm{~A}$ \\
Teknologi Ratun $\left(\mathrm{T}_{4}\right)$ & $6 \mathrm{a}$ & $5 \mathrm{a}$ & $6 \mathrm{a}$ \\
& $\mathrm{A}$ & $\mathrm{A}$ & $\mathrm{A}$ \\
\hline
\end{tabular}

Keterangan: Angka-angka yang diikuti dengan huruf yang tidak sama berbeda nyata menurut uji BNT 0,05. Huruf kecil dibaca vertikal huruf besar dibaca horizontal.

Tabel 6 menunjukkan bahwa rata-rata jumlah anakan produktif tanaman padi akibat teknologi budidaya dan dosis pemupukan NPK Phonska berkisar antara 5 batang per rumpun sampai dengan 15 batang per rumpun. Rata-rata jumlah anakan produktif dipengaruhi nyata oleh teknologi budidaya yang digunakan dan tidak berpengaruh nyata terhadap dosis pemupukan NPK Phonska. Hal ini disebabkan unsur hara yang tersedia di dalam tanah masih mencukupi kebutuhan tanaman.

Anakan produktif padi salibu lebih banyak dibandingkan padi konvensional ini disebabkan karena pengaruh sifat genetik dan lingkungan, seperti ketersediaan air, tingkat kesuburan tanah, sinar matahari, suhu, dan keadaan hama dan penyakit tanaman. Dari aspek fisiologi, aktivitas perakaran padi salibu lebih luas, karakteristik morfologi menunjukkan perakaran lebih kuat, dengan perakaran padi yang luas dan kuat sehingga proses penyerapan unsur hara, hal ini sangat berpengaruh terhadap anakan produktif padi lebih banyak dibandingkan padi konvensional.

Sifat tanaman berdaun sempit mempunyai sifat keturunan yang apabila dipotong ulang akan muncul anakan yang lebih banyak, sesuai yang disampaikan (Baehaki et al., 2010).

Kondisi tanaman setelah panen tanaman utama menunjukkan bahwa kelebihan unsur hara akan dimanfaatkan tanaman sebagai cadangan makanan dan sebahagian akan ditranslokasikan ke daerah pemanfaatan vegetatif. Akar dan batang pada tunggul adalah bagian pemanfaatan hasil fotosintesis selama pertumbuhan ratun. Sisa hasil fotosintesis yang dimanfaatkan akar dan batang mempengaruhi pertumbuhan anakan ratun yang akan muncul dari tunggul, sehingga anakan ratun banyak terbentuk (Gardner, 1991 dalam Susilawati, 2011).

\section{Bobot 1000 Butir Padi}

Hasil analisis ragam menyebutkan bahwa bobot 1000 butir padi tidak dipengaruhi oleh dosis pemberian NPK Phonska tetapi dipengaruhi sangat nyata oleh teknologi budidaya padi yang digunakan serta tidak saling berinteraksi. Rata-rata bobot 1000 butir padi akibat teknologi budidaya padi dan dosis pemberian NPK dapat di lihat pada Tabel 7.

Tabel 7. Rata-rata bobot 1000 butir padi akibat perlakuan teknologi budidaya

\begin{tabular}{lc}
\hline \multicolumn{1}{c}{ Teknologi Budidaya } & $\begin{array}{c}\text { Bobot } 1000 \text { butir } \\
(\mathrm{g})\end{array}$ \\
\hline Sistem tanam 2:1 $\left(\mathrm{T}_{1}\right)$ & $25,167 \mathrm{c}$ \\
Tanam konvensional $\left(\mathrm{T}_{2}\right)$ & $24,944 \mathrm{c}$ \\
Teknologi Salibu $\left(\mathrm{T}_{3}\right)$ & $24,244 \mathrm{~b}$ \\
Teknologi Ratun $\left(\mathrm{T}_{4}\right)$ & $12,178 \mathrm{a}$ \\
\hline
\end{tabular}

Keterangan: Angka-angka yang diikuti dengan huruf yang tidak sama berbeda nyata menurut uji BNT 0,05. Huruf kecil dibaca vertikal huruf besar dibaca horizontal.

Tabel 7 memperlihatkan bahwa rata-rata berat 1000 butir padi akibat teknologi budidaya dan pemberian NPK Phonska berkisar antara $12 \mathrm{~g}$ sampai dengan 25,47 g. Rata-rata berat 1000 butir padi dipengaruhi nyata oleh teknologi budidaya padi yang digunakan dan dipengaruhi secara tidak nyata oleh dosis pemupukan NPK Phonska. 


\section{Berat Gabah per Plot $(\mathrm{Kg})$}

Hasil analisis ragam menunjukkan bahwa berat gabah per plot tanaman padi dipengaruhi sangat nyata oleh teknologi budidaya padi yang digunakan dan dosis pemberian NPK Phonska serta saling berinteraksi. Rata-rata berat gabah per plot padi akibat teknologi budidaya dan pemberian NPK Phonska dapat di lihat pada Tabel 8.

Tabel 8. Rata-rata berat gabah per plot tanaman padi akibat perlakuan teknologi budidaya padi dan dosis pemberian NPK Phonska

\begin{tabular}{|c|c|c|c|}
\hline \multirow{2}{*}{ Teknologi Budidaya } & \multicolumn{3}{|c|}{ NPK Phonska (Kg ha' } \\
\hline & 100 & 200 & 300 \\
\hline & \multicolumn{3}{|c|}{$\ldots \mathrm{kg}$. } \\
\hline \multirow{2}{*}{ Sistem tanam 2:1 $\left(\mathrm{T}_{1}\right)$} & $4,93 \mathrm{~b}$ & $5,97 \mathrm{~d}$ & $6,00 \mathrm{~d}$ \\
\hline & A & B & B \\
\hline \multirow{2}{*}{ Tanam konvensional $\left(\mathrm{T}_{2}\right)$} & $4,53 \mathrm{~b}$ & $5,40 \mathrm{c}$ & $5,47 \mathrm{c}$ \\
\hline & A & B & B \\
\hline \multirow[t]{2}{*}{ Teknologi Salibu $\left(\mathrm{T}_{3}\right)$} & $4,67 \mathrm{~b}$ & $4,82 \mathrm{~b}$ & $4,80 \mathrm{~b}$ \\
\hline & A & A & A \\
\hline \multirow[t]{2}{*}{ Teknologi Ratun $\left(\mathrm{T}_{4}\right)$} & $2,20 \mathrm{a}$ & $2,37 \mathrm{a}$ & 2,33 \\
\hline & A & A & A \\
\hline
\end{tabular}

Keterangan: Angka-angka yang diikuti dengan huruf yang tidak sama berbeda nyata menurut uji BNT 0,05. Huruf kecil dibaca vertikal huruf besar dibaca horizontal

Tabel 8 menunjukkan bahwa rata-rata berat gabah per plot akibat perlakuan teknologi budidaya padi dan dosis pemupukan NPK Phonska berkisar antara 2,20 kg sampai dengan $6 \mathrm{Kg}$. Rata-rata berat gabah per plot meningkat secara konsisten seiring dengan peningkatan takaran NPK Phonska yang diberikan. Berat gabah tertinggi di jumpai pada perlakuan teknologi padi legowo dan perlakuan NPK Phonska $300 \mathrm{~kg} \mathrm{ha}^{-1}$ yaitu $6 \mathrm{~kg}\left(9,6\right.$ ton ha $\left.{ }^{-1}\right)$ yang berbeda nyata dengan setiap taraf perlakuan teknologi budidaya dan dosis pemupukan NPK lainnya yang dicobakan.

Nilai hasil gabah per hektar meningkat 9,71\% dibandingkan potensi hasil varietas ciherang, dan meningkat $50 \%$ dibandingkan rata-rata hasil sekitar lokasi penelitian. Hal ini disebabkan karena dosis pemberian NPK Phonska dapat secara langsung memberikan unsur hara yang dibutuhkan tanaman dan pengaturan sistem jarak tanam padi sistem 2 : 1/legowo (Jurong) berbeda dengan yang dilakukan petani setempat (Sistem Konvensional/Tegel) sehingga berpengaruh terhadap meningkatnya hasil per plot.

Menurut Taslim et al. (1989) komponen hasil berat 1000 butir dan hasil per plot serta panjang malai dipengaruhi oleh faktor genetis dan faktor lingkungan. Kadang-kadang sifat genetis tersebut tidak muncul karena faktor lingkungan tidak sesuai, maka usaha manusia dalam memanfaatkan faktor lingkungan supaya sesuai dan sifat genetis yang diharapkan dapat muncul.

\section{KESIMPULAN DAN SARAN}

Teknologi budidaya memberikan pengaruh sangat nyata terhadap N-total, $\mathrm{pH}\left(\mathrm{H}_{2} \mathrm{O}\right)$, KTK, Corganik, berat 1000 butir, jumlah anakan produktif, hasil panen dan memberikan pengaruh nyata terhadap Kdd. Dosis pemupukan NPK memberikan pengaruh sangat nyata terhadap hasil panen dan memberikan pengaruh nyata terhadap $\mathrm{N}$-total, dan jumlah anakan produktif. Terjadi pengaruh Interaksi yang nyata antara teknologi budidaya dan dosis pemupukan NPK terhadap N-total, jumlah anakan produktif dan hasil panen. Hasil produksi padi terbaik diperoleh pada teknologi budidaya sistem tanam $2: 1 /$ Legowo yang disertai dosis pemupukan NPK Phonska $300 \mathrm{~kg} \mathrm{ha}^{-1}$ sedangkan dari aspek ekonomi teknologi salibu jauh lebih menguntungkan dibandingkan sistem tanam pindah (legowo dan konvensional) karena hemat waktu dan biaya.

\section{DAFTAR PUSTAKA}

Ahmad, S. S. 1987. Pengaruh Pupuk Kalium terhadap Peningkatan Produksi dan Pelestarian Swasembada Pangan di Jawa Barat. Pusat Penelitian Tanah. Bogor. Hal. 3-4. Bandung. 157 hal.

Amang, B. dan M. H. Sawit. 2001. Kebijakan dan Pangan Nasional; Pelajaran dari Orde Baru dan Orde Reformasi. Edisi Press, Bogor.

Badan Penelitian dan Pengembangan Pertanian Kementerian Pertanian, 2013, Buku Petunjuk Penggunaan Perangkat Uji Tanah Sawah, versi 1.1, Bogor.

Badan Penelitian dan Pengembangan Pertanian (BP3) Bogor, 1988. Budidaya Tanaman Padi. Pemerintah Daerah Provinsi Jawa Barat.

Baehaki dkk, 2010, Panduan Umum SL Padi Gogo, BB Padi Sukamandi.

Balai Penyuluhan Pertanian Kembang Tanjong, Laporan Programa Penyuluh Pertanian, 2013, Kembang Tanjong - Pidie.

BPTP Sumatra Barat, 2013, Budidaya Padi Teknologi Salibu (BPTS) Tanam Sekali Panen Berkali-Kali, Padang.

Departemen Pertanian. 2006. Sistem Legowo di Lahan Sawah. Deptan.go.id/ind. Di akses tanggal 12 maret 2014.

Departemen Pertanian. 2008. Panduan Pelaksanaan Sekolah Lapang Pengelolaan Tanaman Terpadu (SL-PTT) Padi. Badan Penelitian dan Pengembangan Pertanian. Jakarta. 
De Datta, S. K. 1981. Principles and Practices of Rice Production. A Wiley InterScience Publications. John Wiley andSons.NewYork. Brisbane. Toronto. $616 \mathrm{p}$.

Dobermann, A. dan T. Fairhust. 2000. Nutrient Disorders and Nutrient Management. Tham Sin Chee. 191p.

Erdiman. 2012. Teknologi Salibu Meningkatkan Produktivitas Lahan (3-6 Ton/Ha/Tahun) dan Pendapatan Petani (Rp.15-25 Juta/Tahun) (Balai Pengkajian Teknologi Pertanian Sumtera Barat).

Gardner, F.P., R. Bren Pearce, Poger R. Michael. 1991. Fisiologi Tanaman Budidaya, Penterjemah Herawati Susilo, UI Press, Jakarta.

Hakim, N., M.Y. Nyakpa, A.M. Lubis, S.G. Nugroho, M.R. Saul, M.A. Diah, Go Ban Hong, H.H. Bailey, 1986, Dasar-Dasar Ilmu Tanah. Bandar Lampung.

Ilham, N., K.Suradisastra, Tri Pranadji, A. Agustian, E. Lestari, H., dan G. S. Hardono, 2008. Analisis Profil Petani dan Pertanian Indonesia. Pusat Analisis Sosial Ekonomi Pertanian dan Kebijakan Pertanian. Badan Litbang Pertanian Departemen Pertanian, Bogor.

Ismunadji,M., S., Partohardjono, \& Sastijati. 1987. Peranan Kalium dalam Meningkatkan Produksi Tanaman Pangan. Lembaga PenelitianHortikultura. Jakarta. 21 hal.

Sufardi, 2012. Pengantar Nutrisi Tanaman, Syiah Kuala University Press, Banda Aceh.

Sulaeman, Suparto dan Eviati, 2005. Analisis Kimia Tanaman, Air dan Pupuk. Badan Penelitian dan Pengembangan Pertanian. Departemen Pertanian. Bogor.

Susilawati. 2011. Agronomi Ratun Genotipe Genotipe Padi Potensial Untuk Lahan Pasang Surut. Disertasi Pasca Sarjana Institut Pertanian Bogor, 94 Hal.

Susilawati., B.S. Purwoko, H. Aswidinnoor, E. Santosa. 2010. Keragaan varietas dan galur padi tipe baru Indonesia dalam sistem ratun. J. Agron. Indonesia. 38:177-184.

Yohanes. 2012. Tanam Sekali Panen Berkali-Kali Dengan Teknologi Padi Salibu. UPT Dinas Pertanian dan Kehutanan Kab. Tanah Datar Kecamatan Lima Kaum, 22 Hal. 